\title{
Follicular Lymphoma Diagnosed in Warthin Tumor: A Case Report and Review of the Literature
}

\author{
Fnu Alnoor ${ }^{1,3}$ (D) Jatin S. Gandhi ${ }^{1} \cdot$ Matthew K. Stein $^{2} \cdot$ Joel F. Gradowski $^{1}$
}

Received: 6 April 2019 / Accepted: 5 June 2019 / Published online: 10 June 2019

(c) Springer Science+Business Media, LLC, part of Springer Nature 2019

\begin{abstract}
Warthin tumor is one of the most common benign salivary gland tumors. It is unusual and difficult to diagnose follicular lymphoma within the lymphoid tissue of Warthin tumor. We present a rare case of a 69 -year-old man with systemic follicular lymphoma initially diagnosed in a Warthin tumor. Lymphomas occurring within Warthin tumors are rare, however, follicular lymphoma is most commonly reported. Because these patients require further treatment depending on the stage of a disease, it is important for a pathologist to review the histology of Warthin tumors diligently to identify occult lymphomas.
\end{abstract}

Keywords Parotid gland $\cdot$ Lymph node $\cdot$ Warthin tumor $\cdot$ Hodgkin lymphoma $\cdot$ Non-Hodgkin lymphoma $\cdot$ Follicular lymphoma

\section{Background}

Warthin tumor, previously described as cystadenoma lymphomatosum papilliferum, is found exclusively in the parotid gland and peri-parotid lymph nodes [1]. It is a benign adenoma composed of varying component of bilayer columnar and basaloid oncocytic epithelium associated with an underlying lymphoid stroma that often contains prominent lymphoid follicles with reactive germinal centers [2]. Warthin tumor rarely undergoes malignant transformation. The epithelial component may evolve into adenocarcinoma, mucoepidermoid carcinoma, squamous cell carcinoma, oncocytic carcinoma, Warthin adenocarcinoma [3-7], while the lymphoid component may be involved by malignant lymphoma [2, 8-11]. Only a few cases of Hodgkin lymphoma (HL) and non-Hodgkin lymphoma (NHL) associated with Warthin tumor have been reported in the

Fnu Alnoor

falnoor@uthsc.edu

1 Department of Pathology and Laboratory Medicine, University of Tennessee Health Science Center, Memphis, TN, USA

2 Division of Hematology and Oncology, University of Tennessee Health Science Center, Memphis, TN, USA

3 Department of Pathology and Laboratory Medicine, University of Tennessee Health Science Center, 930 Madison Avenue, Suite 525, Memphis, TN 38163, USA literature. Interestingly, among the NHL associated with Warthin tumor, the most commonly reported type of NHL was follicular lymphoma [2, 8, 10-18]. We report the 14th case (in the English literature) of follicular lymphoma first detected within Warthin tumor in a 69-year-old gentleman. This case highlights the utmost importance of careful light microscopic evaluation of the lymphoid follicles within Warthin tumors to identify occult lymphoma.

\section{Materials and Methods}

The patient's clinical history, laboratory data and follow up were obtained from the hospital's electronic medical records and patient's physician. The patient's specimen was received at Methodist University Hospital, Memphis. The hematoxylin and eosin slide was prepared using paraffin block 4 um section and stained by a standard method. Immunohistochemistry (IHC) studies using paraffin embedded tissue sections were performed on a fully automated IHC stainer, Leica BOND-III (Ventana). The details of antibody clones, retrieval method, RT and dilution are summarized in Table 1. Flow cytometry study on patient's specimen was performed using four color Beckman Coulter Cytomics FC500 Flow cytometer analyzer (software, CXP Cytometry, V 2.3). 
Table 1 Details of immunohistochemistry details of antibodies and their clones

\begin{tabular}{llllllllll}
\hline & CD 3 & CD 20/L26 & BCL-2 & BCL-6 & CD 10 & CD 5 & Cyclin D1 & Ki-67/MIB1 & CD 21 \\
\hline Manufacture & Leica & Cell Marque & Leica & Leica & Leica & Leica & Cell Marque & Cell Marque & Cell Marque \\
Ab Clone & LN10 & SP32 & Bcl-2/100/DS & LN22 & 56CL & 4C7 & SP4 & SP6 & 2G9 \\
Retrieval method & HIER & ER1 & ER2 & ER2 & ER2 & ER2 & ER2 & CC1 & CC1 \\
& ER2 & 10 min & 20 min & 30 min & 20 min & 20 min & 20 min & 8 min & 8 min \\
& 10 min & $100^{\circ}$ & $100^{\circ}$ & $100^{\circ}$ & $100^{\circ}$ & $100^{\circ}$ & $100^{\circ}$ & $95^{\circ}$ & $95^{\circ}$ \\
RT/dilution & $100^{\circ}$ & & & & & & & $1: 100$ & RT4 \\
\hline
\end{tabular}

\section{Case}

A 69-year-old male presented with a left neck painless mass for 3 months with a recent onset of right sided neck swelling for 2 weeks. The patient denied any fever, night sweats, or weight loss (B symptoms). His past medical history was significant for chronic smoking (55 pack year), atrial fibrillation, pacemaker placement, and cholecystectomy. The family history was significant for colon cancer. On complete physical examination, there were two palpable swellings, a $4 \mathrm{~cm}$ and a $1 \mathrm{~cm}$ below and inferior to the left parotid gland, and along with multiple sub-centimeter lymph nodes were palpated on the contralateral side. A computed tomography (CT) scan confirmed the presence of bilateral lymphadenopathy. Fine needle aspiration of the left neck mass performed at an outside facility displayed oncocytic epithelial cells with eosinophilic cytoplasm characteristic of Warthin tumor along with a population of lymphoid cells which raised concern for lymphoma.
The parotid mass on the left side was surgically excised and sent to the hematopathology section for evaluation.

Flow cytometric immunophenotypic studies performed on the left neck mass demonstrated 50\% B-cells that included a population of $\mathrm{CD} 20$ positive, $\mathrm{CD} 5$ negative, $\mathrm{CD} 10$ positive, surface immunoglobulin negative B-cells. The remaining B-cells had polytypic surface light chain expression. T-cells were $43 \%$ of the total cells and did not show loss of pan $\mathrm{T}$ cell antigens. The CD4:CD8 ratio was 5:1.

The surgically excised specimen received in formalin consisted of two tan-pink portions of soft tissue measuring $2.0 \times 0.5 \times 0.5 \mathrm{~cm}^{3}$ and $1.6 \times 1.5 \times 1.0 \mathrm{~cm}^{3}$. Examination of the histologic sections revealed a peri-parotid lymph node. The lymph node was replaced by a tumor comprising of cystic structure lined by oncocytic luminal tall columnar cells with eosinophilic cytoplasm and a basal layer of bland cuboidal cells. The basal cells had round to oval nuclei and small but conspicuous nucleoli. The lumina of the cysts contained eosinophilic secretions admixed with
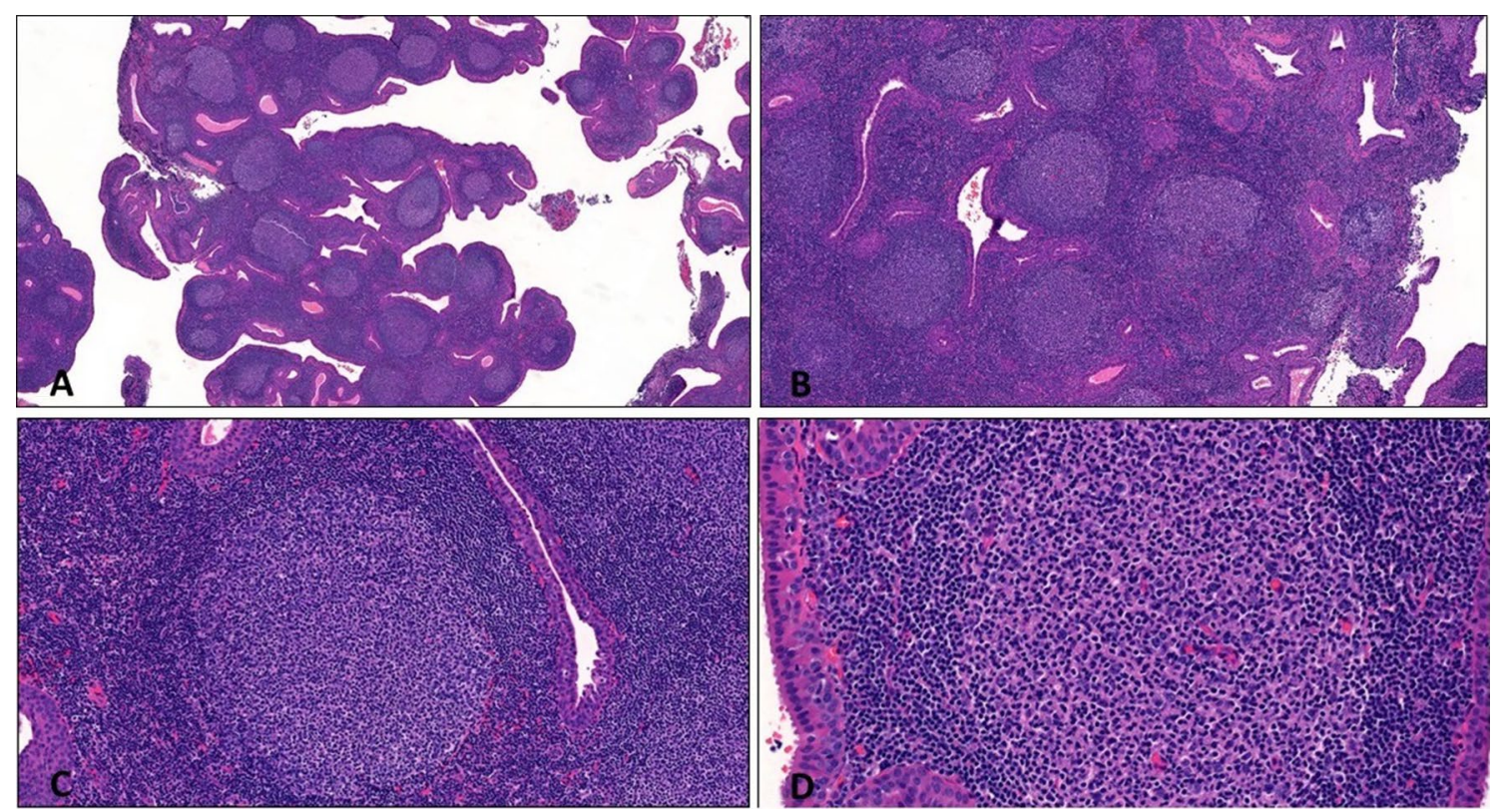

Fig. 1 Warthin tumor and follicle center lymphoma, follicular, grade 1-2. a, b Warthin tumor epithelium and many neoplastic follicles (H\&E, $\times 2$ and $\times 4)$. c, $\mathbf{d}$ Neoplastic follicles are composed of small cleaved lymphoid cells $(H \& \mathrm{E}, \times 10$ and $\times 20)$ 
cell debris. These findings were diagnostic of Warthin tumor (Fig. 1a, b). The sub-epithelial lymphoid stroma was composed of numerous uniform sized lymphoid follicles with germinal centers (Fig. 1c, d). The follicles exhibited loss of polarity with a monotonous population of centrocytes. Immunohistochemical studies were performed. The cells within the follicles were strongly positive for CD20, CD10, and BCL-6. The monotonous germinal centers were BCL-2 positive. Ki-67 displayed scattered positivity within the germinal centers (Fig. 2). These findings were diagnostic of grade 1-2 follicular lymphoma with a follicular growth pattern. Complete blood profile, liver function test, metabolic panel, and LDH were normal while beta-2 microglobulin was $2.4 \mathrm{mg} / \mathrm{L}$ (normal range $0.8-2.2 \mathrm{mg} / \mathrm{L}$ ). Positron emission tomography (PET) scan showed $11 \mathrm{~mm}$ hypermetabolic nodule in the superficial left parotid with lymphomatous involvement of bilateral cervical, left axillary, and likely involvement of inguinal lymph nodes. There were multifocal lesions in the spine and bony pelvis likely representing osseous lymphoma with no signs of the fractures. The patient's disease was staged as stage IV lymphoma. At the time of the patient's most recent visit, he gained weight and remained asymptomatic, and therefore no treatment was initiated. The patient was closely followed up for 3 months without any symptoms. He has been prescribed Denosumab $120 \mathrm{mg}$ SQ q28d with Citracel $1200 \mathrm{mg}$ for bony lesions.
Table 2 Summary of malignant lymphoma associated with Warthin tumor

\begin{tabular}{ll}
\hline & Frequency $(\mathrm{n})$ \\
\hline Hodgkin lymphoma $(\mathrm{n}=6,18.2 \%)$ & \\
CHL, mixed cellularity & $2[19,20]$ \\
CHL, lymphocyte rich & $1[21]$ \\
CHL (Not distinguished) & $2[22,34]$ \\
NLPHL & $1[23]$ \\
Non-Hodgkin Lymphoma $(\mathrm{n}=27,82.8 \%)$ & \\
Follicular lymphoma & $13[2,8,10-18]$ \\
DLBCL & $5[14,24-27]$ \\
Small lymphocytic lymphoma & $3[9,28,29]$ \\
Mantle cell lymphoma & $2[2,30]$ \\
MALT-type lymphoma & $1[31]$ \\
Peripheral T cell lymphoma & $1[32]$ \\
T cell-lymphoblastic lymphoma & $1[33]$ \\
Unclassified & $1[17]$
\end{tabular}

\section{Discussion}

Detection of a malignancy concurrently in Warthin tumor was first documented in 1954 [10]. Review of the English language literature revealed rare reports of lymphoma diagnosed within Warthin tumor. Thirty-four cases (including the present case) of lymphoma have been reported in association with Warthin tumor of which 28 were NHL and 6 were HL. Follicular lymphoma was most commonly reported
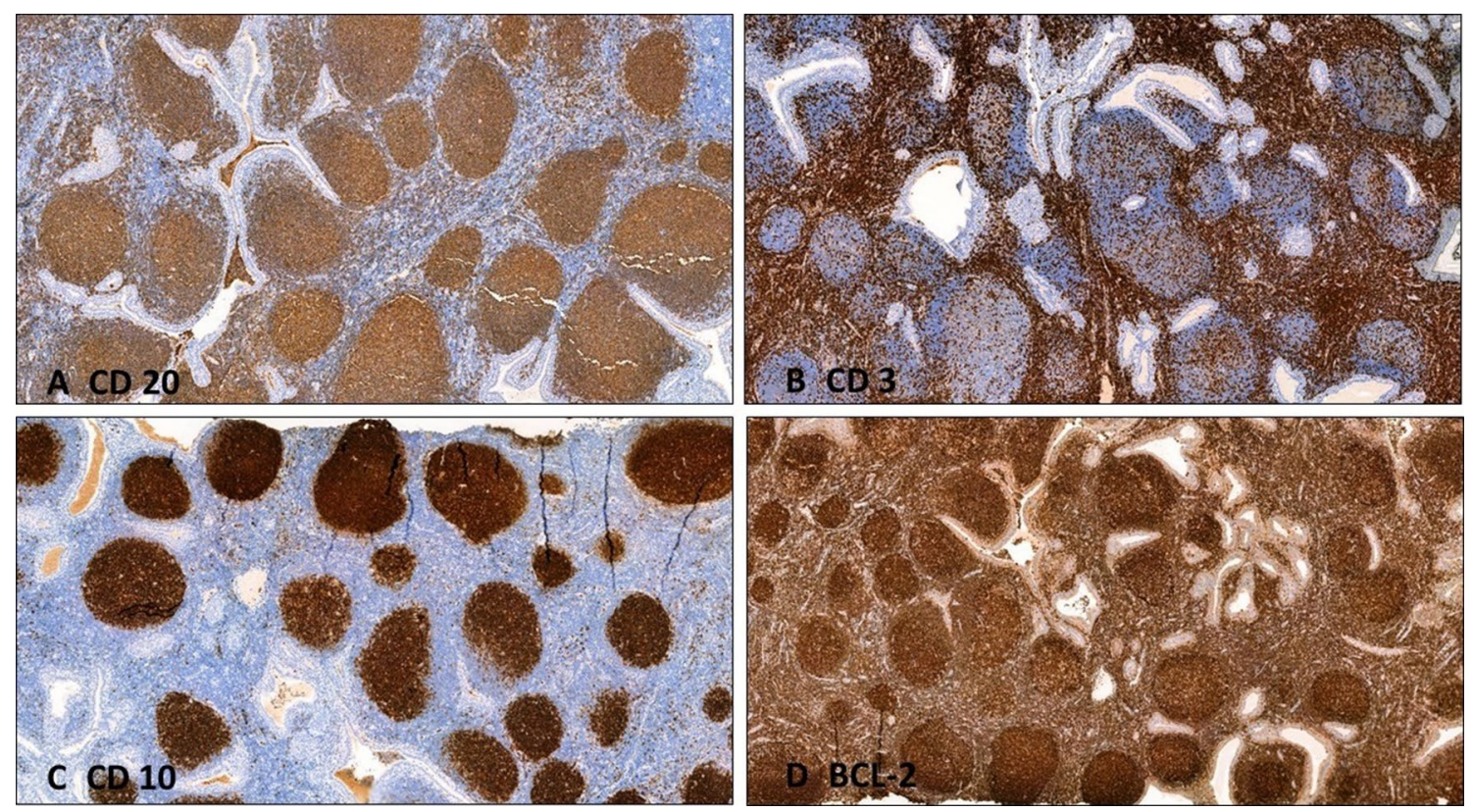

Fig. 2 Warthin tumor and follicle center lymphoma, follicular, grade 1-2. a CD 20 positive B cell follicles. b Inter follicular area CD 3 positive T cells. c, d Strongly positive follicles with CD 10, and BCL-2 
(Table 2). Due to the rarity of follicular lymphoma in association with Warthin tumor, the pathogenic relationship is uncertain, and the occurrence of both entities simultaneously may be coincidence.

Including the present case, follicular lymphoma represented 14 out of 28 (50\%) of the reported NHL cases. The follicular lymphomas were predominantly low grade (grade 1-2 of 3) [2, 8, 10-18]. The overall incidence of follicular lymphoma among all type of lymphoma associated with Warthin tumor is $41.2 \%$ (14/34) making follicular lymphoma the most common type of NHL detected in Warthin tumor. The age distribution ranged from 49 to 83 years with a mean age of 66.6 years and standard deviation (SD) of 10.6 years [11]. Our patient falls within the age range of one SD of mean age. Warthin and follicular lymphoma association are far more frequent in males $(77 \%, \mathrm{n}=10)$ than females $(23 \%, \mathrm{n}=3)$. The recognized patterns of involvement by follicular lymphoma included follicular $(63 \%, \mathrm{n}=7)$, diffuse pattern $(10 \%, \mathrm{n}=1)$ and mixed follicular and diffuse $(27 \%, \mathrm{n}=3)$. The present case was low-grade (grade 1-2/3) with a follicular growth pattern. The most common site for follicular lymphoma in Warthin tumor is a parotid gland. Giardini et al. reported bilateral parotid gland Warthin tumor involvement with follicular lymphoma [12]. Reiner et al. reported a case of large cell lymphoma in association with Warthin tumor, in a patient having preexisting Sjogren syndrome [19]. Generally, a bone marrow biopsy for these patients may

Table 3 Summary of follicular lymphoma detected in association with Warthin tumor

\begin{tabular}{|c|c|c|c|c|c|c|c|c|c|}
\hline Study & Year & Age & Sex & Location & Pattern & Grade & Stage & $\begin{array}{l}\text { Other organs involved at } \\
\text { diagnosis/treatment }\end{array}$ & Follow up \\
\hline Colby et al. [17] & 1979 & NA & NA & Parotid & $\mathrm{F}$ & 1 & NA & Regional LNs & NA \\
\hline Seifert et al. [2] & 1980 & 83 & M & Parotid & NA & NA & NA & Regional LNs & NA \\
\hline Miller et al. [16] & 1982 & 49 & M & Angle of mandible & NA & 1 & IA & None & $\begin{array}{l}3 \text { months later surgical } \\
\text { excision of regional LNs } \\
\text { had NHL }\end{array}$ \\
\hline \multirow[t]{2}{*}{ Banik et al. [8] } & \multirow[t]{2}{*}{1984} & 75 & M & Left parotid & D & 2 & NA & None & NA \\
\hline & & 76 & M & Right parotid & $\mathrm{F}+\mathrm{D}$ & 2 & IIIA & $\begin{array}{l}\text { Generalized LNs (CT: } \\
\text { chlorambucil and pred- } \\
\text { nisone) }\end{array}$ & $\begin{array}{l}\text { NHL in neck LNs } 1 \text { year } \\
\text { later }\end{array}$ \\
\hline Hall et al. [15] & 1985 & 64 & M & Right parotid & $\mathrm{F}+\mathrm{D}$ & 2 & IA & None & $\begin{array}{l}\text { Generalized NHL } 7 \text { months } \\
\text { later }\end{array}$ \\
\hline Griesser et al. [14] & 1986 & 64 & $\mathrm{~F}$ & Palate & $\mathrm{F}$ & 2 & NA & NA & NA \\
\hline Medeiros et al. [13] & 1990 & 71 & M & Left parotid & $\mathrm{F}+\mathrm{D}$ & 2 & IIIA & $\begin{array}{l}\text { Periaortic LNs (CT: V-16; } \\
\text { adriamycin, cyclophos- } \\
\text { phamide, vincristine, } \\
\text { prednisone, bleomycin) }\end{array}$ & NED 48 months later \\
\hline Giardini et al. [12] & 1990 & 57 & M & Right and left parotid & $\mathrm{F}$ & 1 & IIA & $\begin{array}{l}\text { Regional LNs (CT: } \\
\text { endoxan, vincristine, } \\
\text { predinisone) }\end{array}$ & NED 3 years later \\
\hline Shikhani et al. [10] & 1993 & 56 & M & Right Parotid & NA & NA & IA & None (RT: 4500 rads) & $\begin{array}{l}\text { Axillary LN recurrence } \\
4 \text { years } 4 \text { months later. } \\
\text { Died of generalized } \\
\text { NHL } 7 \text { years after initial } \\
\text { diagnosis }\end{array}$ \\
\hline \multirow[t]{2}{*}{ Park et al. [11] } & 2000 & 68 & $\mathrm{~F}$ & Right peri-parotid LN & $\mathrm{F}$ & 1 & IA & None (RT: unknown dose) & $\begin{array}{l}4.5 \text { years later inguinal LN } \\
\text { NHL, complete clinical } \\
\text { remission after combina- } \\
\text { tion CT }\end{array}$ \\
\hline & & 55 & M & Right parotid & $\mathrm{F}$ & 1 & IIA & Axillary LN & NA \\
\hline Romero et al. [18] & 2016 & 82 & $\mathrm{~F}$ & Right Parotid & $\mathrm{F}$ & Low & IV & $\begin{array}{l}\text { None (CT: } 4 \text { cycles of } \\
\text { Rituximab) }\end{array}$ & Improved thrombocytopenia \\
\hline Present case & 2018 & 69 & M & Right neck LN & $\mathrm{F}$ & $1-2$ & IV & $\begin{array}{l}\text { Generalized LNs, Spine } \\
\text { and Pelvic bone (No CT } \\
\text { or RT given) }\end{array}$ & Recent study \\
\hline
\end{tabular}

Diagnosis translated into terminology according to World Health Organization Classification of Tumors when possible

$F$ follicular; $D$ diffuse; $L N$ lymph node; $N H L$ non-Hodgkin lymphoma; $N A$ not available; $N E D$ no evidence of disease; $C T$ chemotherapy; $R T$ radiation therapy 
show involvement by small clonal B cell population. Most of the patients have either nodal or visceral organ involvement by follicular lymphoma at the time of diagnosis $[2,8$, 11-13, 17]. PET scan in our patient showed a disseminated lymphoma involving generalized lymph nodes above and below the diaphragm, with lesions in the spine and pelvic bones. The patient is currently being followed up in the outpatient department setting with regular clinical checkups and laboratory workup as necessary. Table 3 summarizes all the Warthin tumor associated follicular lymphoma cases found in the literature including tumor grading, stage and follow up.

In summary, Warthin tumor can predispose to an epithelial malignancy or malignant lymphoma. We report a case of an initial diagnosis of low-grade follicular lymphoma associated with Warthin tumor in a peri-parotid lymph node. Although rare, this finding demonstrates that patients in 4th to 8th decade of life could have first time diagnosis of lymphoma in association with a benign tumor, like Warthin tumor. Therefore, it is crucial for pathologists to be aware of this potential presentation and carefully examine on light microscopy the lymphoid follicles of Warthin tumor and make judicious use of ancillary studies to rule out occult lymphoma.

\section{Compliance with Ethical Standards}

Conflict of interest All authors have no conflicts of interest to disclose.

\section{References}

1. Eveson JW, Cawson RA. Warthin's tumor (cystadenolymphoma) of salivary glands. A clinicopathologic investigation of 278 cases. Oral Surg Oral Med Oral Pathol. 1986;61:256-62.

2. Seifert G, Bull HG, Donath K. Histologic subclassification of the cystadenolymphoma of the parotid gland. Analysis of 275 cases. Virchows Archiv A. 1980;388:13-38.

3. Smolka W, Markowski J, Piotrowska-Seweryn A, Palen P, Dobrosz Z, Dziubdziela W. Mucoepidermoid carcinoma in Warthin tumor of the parotid gland. Arch Med Sci. 2015;11(3):691-5.

4. Bengoechea O, Sanchez F, Larrinaga B, Martinez-Penuela JM. Oncocytic adenocarcinoma arising in Warthin's tumor. Pathol Res Pract. 1989;185:907-11 discussion 11-4.

5. Williamson JD, Simmons BH, el-Naggar A, Medeiros LJ. Mucoepidermoid carcinoma involving Warthin tumor A report of five cases and review of the literature. Am J CLIN PATHol. 2000;114:564-70.

6. Yu C, Song Z, Xiao Z, Lin Q, Dong X. Mucoepidermoid carcinoma arising in Warthin's tumor of the parotid gland: clinicopathological characteristics and immunophenotypes. Sci Rep. 2016;6:30149.

7. Yaranal PJ. Squamous cell carcinoma arising in Warthin's tumour: a case report. J Clin Diagn Res. 2013;7:163-5.

8. Banik S, Howell JS, Wright DH. Non-Hodgkin's lymphoma arising in adenolymphoma-a report of two cases. J Pathol. 1985;146:167-77.
9. Bunker ML, Locker J. Warthin's tumor with malignant lymphoma DNA analysis of paraffin-embedded tissue. Am J Clin Pathol. 1989;91:341-4.

10. Shikhani AH, Shikhani LT, Kuhajda FP, Allam CK. Warthin's tumor-associated neoplasms: report of two cases and review of the literature. Ear Nose Throat J. 1993;72(264-9):72-3.

11. Park CK, Manning JT, Battifora H, Medeiros LJ. Follicle center lymphoma and Warthin tumor involving the same anatomic site. Report of two cases and review of the literature. Am J Clin Pathol. 2000;113:113-9.

12. Giardini R, Mastore M. Follicular non Hodgkin's lymphoma in adenolymphoma: report of a case. Tumori. 1990;76:212-5.

13. Medeiros LJ, Rizzi R, Lardelli P, Jaffe ES. Malignant lymphoma involving a Warthin's tumor: a case with immunophenotypic and gene rearrangement analysis. Hum Pathol. 1990;21:974-7.

14. Griesser GH, Hansmann ML, Bogman MJ, Pielsticker K, Lennert $\mathrm{K}$. Germinal center derived malignant lymphoma in cystadenolymphoma. Virchows Archiv A. 1986;408:491-6.

15. Hall G, Tesluk H, Baron S. Lymphoma arising in an adenolymphoma. Hum Pathol. 1985;16(4):424-7.

16. Miller R, Yanagihara ET, Dubrow AA, Lukes RJ. Malignant lymphoma in the Warthin's tumor. Report of a case. Cancer. 1982;50:2948-50.

17. Colby TV, Dorfman RF. Malignant lymphomas involving the salivary glands. Pathol Annu. 1979;14(Pt 2):307-24.

18. Romero M, Gonzalez-Fontal GR, Duarte M, Saavedra C, HenaoMartinez AF. Small clonal B-cell population in the bone marrow as a possible tool in the diagnosis of occult primary parotid lymphoma. Colombia medica (Cali, Colombia). 2016;47:59-62.

19. Jun L, Ming Z. Classical Hodgkin lymphoma arising from heterotopic Warthin's tumor in the cervical lymph node: a case report. Oncol Lett. 2018;16:619-22.

20. Melato M, Falconieri G, Fanin R, Baccarani M. Hodgkin's disease occurring in a Warthin's tumor: first case report. Pathol Res Pract. 1986;181:615-20.

21. Liu YQ, Tang QL, Wang LL, Liu QY, Fan S, Li HG. Concomitant lymphocyte-rich classical Hodgkin's lymphoma and Warthin's tumor. Oral Surg Oral Med Oral Pathol Oral Radiol. 2013;116:e117-20.

22. Badve S, Evans G, Mady S, Coppen M, Sloane J. A case of Warthin's tumour with coexistent Hodgkin's disease. Histopathology. 1993;22:280-1.

23. Di Napoli A, Mallel G, Bartolazzi A, Cavalieri E, Becelli R, Cippitelli $\mathrm{C}$, et al. Nodular lymphocyte-predominant Hodgkin lymphoma in a Warthin tumor of the parotid gland: a case report and literature review. Int J Surg Pathol. 2015;23:419-23.

24. Chu CY, Pan SC, Chang KC. EBV-positive diffuse large B-cell lymphoma of the elderly involving Warthin tumor. Pathol Int. 2015;65:677-9.

25. Ozkok G, Tasli F, Ozsan N, Ozturk R, Postaci H. Diffuse large B-Cell lymphoma arising in Warthin's tumor: case study and review of the literature. Korean J Pathol. 2013;47:579-82.

26. Gorai S, Numata T, Kawada S, Nakano M, Tamaru J, Kobayashi T. Malignant lymphoma arising from heterotopic Warthin's tumor in the neck: case report and review of the literature. Tohoku J Exp Med. 2007;212:199-205.

27. Reiner M, Goldhirsch A, Luscieti PR, Pedrinis E, Kaplan E, Cavalli F. Warthin's tumor with Sjogren's syndrome and nonHodgkin's lymphoma. Ear Nose Throat J. 1979;58:345-50.

28. Jawad H, McCarthy P, O'Leary G, Heffron CC. Presentation of chronic lymphocytic leukemia/small lymphocytic lymphoma in a Warthin tumor: case report and literature review. Int J Surg Pathol. 2018;26:256-60.

29. Saxena A, Memauri B, Hasegawa W. Initial diagnosis of small lymphocytic lymphoma in parotidectomy for Warthin tumour, a rare collision tumour. J Clin Pathol. 2005;58:331-3. 
30. Arcega RS, Feinstein AJ, Bhuta S, Blackwell KE, Rao NP, Pullarkat ST. An unusual initial presentation of mantle cell lymphoma arising from the lymphoid stroma of warthin tumor. Diagn Pathol. 2015;10:209.

31. Marioni G, Marchese-Ragona R, Marino F, Poletti A, Ottaviano $\mathrm{G}$, de Filippis C, et al. MALT-type lymphoma and Warthin's tumour presenting in the same parotid gland. Acta Otolaryngol. 2004;124:318-23.

32. Pescarmona E, Perez M, Faraggiana T, Granati L, Baroni CD. Nodal peripheral T-cell lymphoma associated with Warthin's tumour. Histopathology. 2005;47:221-2.
33. Giaslakiotis K, Androulaki A, Panagoulias G, Kyrtsonis MC, Lazaris AC, Kanakis DN, et al. T cell lymphoblastic lymphoma in parotidectomy for Warthin's tumor: case report and review of the literature. Int J Hematol. 2009;89:359-64.

34. Cozzolino I, Zeppa P, Cuccuru A, Picardi M, Vetrani A, Palombini L. Collision Hodgkin lymphoma and Warthin tumour Report of a case and review of the literature. Oral Surg. 2009;2:188-92.

Publisher's Note Springer Nature remains neutral with regard to jurisdictional claims in published maps and institutional affiliations. 